\title{
Brunaslys barna: Innlagnir á Landspítala 2000-2008
}

\section{Ágrip}

Lovísa

Baldursdóttir ${ }^{1}$

hjúkrunarfræðingur

Laura Scheving

Thorsteinsson ${ }^{2}$

hjúkrunarfræðingur

Gunnar

Auðólfsson ${ }^{3}$

lýtalæknir

Margrét E.

Baldursdóttir ${ }^{4}$

hjúkrunarfræðingur

Berglind Ó.

Sigurvinsdóttir ${ }^{3}$

hjúkrunarfræðingur

Vilborg

Gísladóttir ${ }^{5}$

hjúkrunarfræðingur

\section{Anna Ólafía \\ Sigurðardóttir ${ }^{4}$ \\ hjúkrunarfræðingur}

Práinn

Rósmundsson ${ }^{4}$

barnaskurðlæknir

Lykilorð: brunaslys, börn, forvarnir, faraldsfræði.

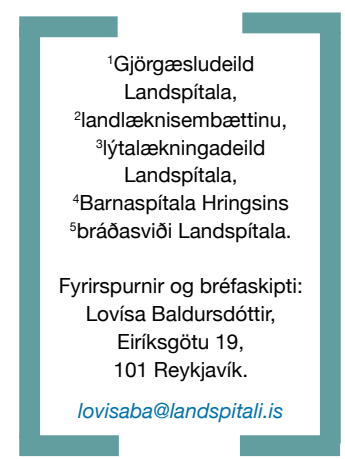

Tilgangur: Að afla upplýsinga um brunaslys barna sem lögðust inn á Landspítala á níu ára tímabili, meta hvort efla purfi forvarnir og endurskoða ákveðna pætti í meðferð.

Aðferðir: Í pessari afturskyggnu lýsandi rannsókn var upplýsingum safnað úr sjúkraskrám um börn yngri en átján ára sem dvöldu lengur en sólarhring á Landspítala vegna brunaáverka á húo á árunum 2000-2008.

Niðurstöður: Af 149 börnum voru 108 drengir og 41 stúlka. Meðalfjöldi innlagna á ári var 16,5 eða $21 / 100000$. Brunaslys voru algengust hjá fjögurra ára og yngri (41,6\%) og í aldurshópnum 13-16 ára $(45,7 \%)$. Hjá meirihlutanum $(81 \%)$ var útbreiðsla áverka $\leq 10 \%$ af líkamsyfirborði. Helmingur slysa varð inni á heimili. Sár voru kæld á vettvangi í 78\% tilvika. Áhættupættir voru til staðar hjá $11,4 \%$ barna og hjá 3,4\% barna var grunur um vanrækslu eða ofbeldi. Helstu brunavaldar voru heitt vatn og aðrir heitir vökvar (50,3\%), par af neysluvatn í 12,9\% tilvika, eldur í 20,4\% tilvika, par af gas eða bensín hjá 14,9\% barna, og skoteldar (17,6\%). Meðaltími frá komu á bráđamóttöku að innlögn á barnadeild var 142 mínútur, (25-333). Meðallegutími var 13 dagar, miðgildið níu dagar (1-97) að meðtöldum sex dögum á gjörgæsludeild, miðgildið tveir dagar (1-48) .

Ályktun: Innlögnum vegna brunaáverka hefur fækkað. Algengustu brunavaldar eru heitt vatn, heitir vökvar, eldur og skoteldar. Flest eru slysin hjá börnum yngri en fjögurra ára og hjá drengjum 13-16 ára. Mikilvægt er að auka öryggi barna á heimilum og beina forvörnum að áhættuhópum. Vanda parf fyrsta mat á útbreiðslu sára og greina pætti sem hafa áhrif á dvalartíma á bráđamóttöku og legudeild. Bæta parf skráningu í sjúkraskrá.

\section{Inngangur}

Brunaslys eru alvarlegt heilsufarsvandamál víða í veröldinni og algeng orsök fötlunar og líkamslýta. ${ }^{1}$ Orsakir brunaslysa eru tengdar samfélagsgerð og pví breytilegar eftir löndum og eru brunaslys tíðust hjá fátækum pjóðum. ${ }^{1,2}$ Niðurstöður rannsókna benda til pess að börn fjögurra ára og yngri séu í mestri hættu, drengir lendi frekar í brunaslysum en stúlkur og að heimilið sé algengasti vettvangur slysanna. ${ }^{2-8}$ Heitt vatn og aðrir heitir vökvar eru algengasta orsök bruna hjá ungum börnum í vestrænum ríkjum en eldur hjá vanpróuðum pjóðum., 2, 4-7 Fylgikvillar stærri brunaáverka eru lífshættulegir og prátt fyrir framfarir í meðferð sem hafa lækkað dánartíðni og stytt legutíma, pá ber barnið líkamlegar og sálrænar menjar brunaslyssins allt lífið. Áhrif brunalosts og sýkinga og flókin sárameðferð leiða til langrar sjúkrahúsdvalar og aðskilnaðar frá fjölskyldu og vinum. Einnig geta endurhæfing og lýtaaðgerðir náð yfir ár og áratugi. Pekkt er að brunaslys hafa áhrif á sálfélagslega líðan barna og má nefna punglyndi, kvíða og einangrun ${ }^{9}$ og áfallastreituröskun. ${ }^{10}$

Samanburður rannsókna á brunaslysum er erfiður vegna ólíkrar aðferðafræði og mismunandi skilgreininga og máparnefnaaldursviðmið, viðmið fyrir innlögn á sjúkrahús og talningu legudaga. ${ }^{2}$ Prjár rannsóknir á brunaslysum barna á Íslandi hafa verið birtar (tafla I) ${ }^{11-13}$ og samræmast niður-

Tafla I. Íslenskar rannsóknir á brunaslysum barna. ${ }^{11-13}$

\begin{tabular}{|c|c|c|c|}
\hline Tímabil & $1957-1969^{11}$ & $1964-1973^{12}$ & $1982-1995^{13}$ \\
\hline Aldur & $\begin{array}{c}12 \text { ára og } \\
\text { yngri }\end{array}$ & $\begin{array}{c}12 \text { ára og } \\
\text { yngri }\end{array}$ & $\begin{array}{c}15 \text { ára og } \\
\text { yngri }\end{array}$ \\
\hline Fjöldi (N) & 185 & 215 & 290 \\
\hline Innlagnir/ár & 14,2 & 21,5 & 20,7 \\
\hline Nýgengi & ep & ep & $30,4 / 100000^{*}$ \\
\hline Börn $\leq 2$ ára & ep & $45,1 \%$ & $61,7 \%$ \\
\hline Börn $\leq 4$ ára & ep & $80,4 \%$ & $72,8 \%$ \\
\hline $\begin{array}{l}\text { TBSA }<10 \% \\
\text { TBSA }>20 \%\end{array}$ & ep & ep & $\begin{array}{c}72,4 \% \\
7,6 \% \\
\end{array}$ \\
\hline Meðallegutími & 26 dagar & 20,7 dagar & 12 dagar \\
\hline Slys á heimili & ep & $86,5 \%$ & $81,4 \%$ \\
\hline - Vatn, vökvar & $66 \%$ & $75,3 \%$ & $72,1 \%$ \\
\hline - Neysluvatn & ep & ep & $15,2 \%$ \\
\hline - Hveravatn & ep & ep & ep \\
\hline - Eldur & $17 \%$ & $7,9 \%$ & $12,4 \%$ \\
\hline - Skoteldar & ep & ep & $5,5 \%$ \\
\hline - Bensín, gas & ep & $1,4 \%$ & 5,2 \\
\hline - Snertibruni & $5 \%$ & $4,7 \%$ & $5,2 \%$ \\
\hline - Ætandi efni & $5 \%$ & $1,9 \%$ & $1 \%$ \\
\hline - Rafmagn & $7 \%$ & $3,7 \%$ & $0,3 \%$ \\
\hline
\end{tabular}




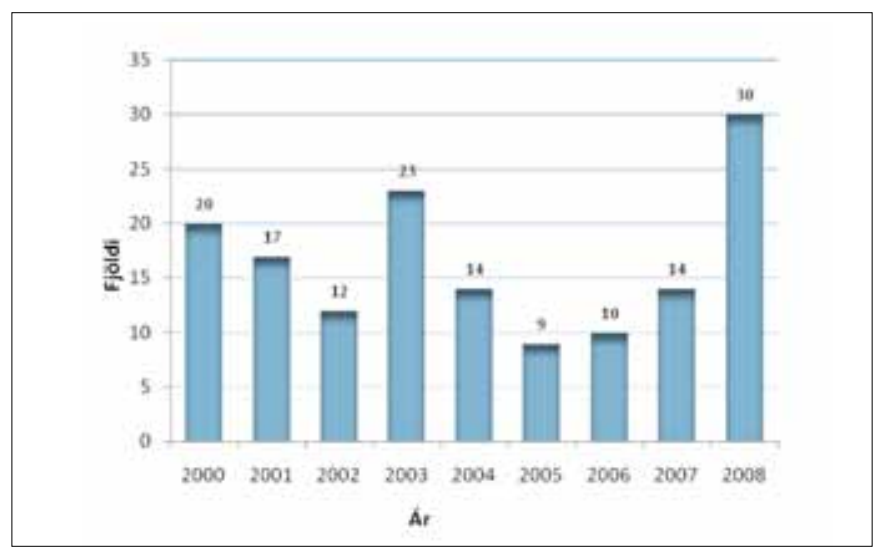

Mynd 1. Innlagnir barna á Landspitala lengur en í sólarhring vegna brunaslysa árin 2000-2008 ( $n=149)$.

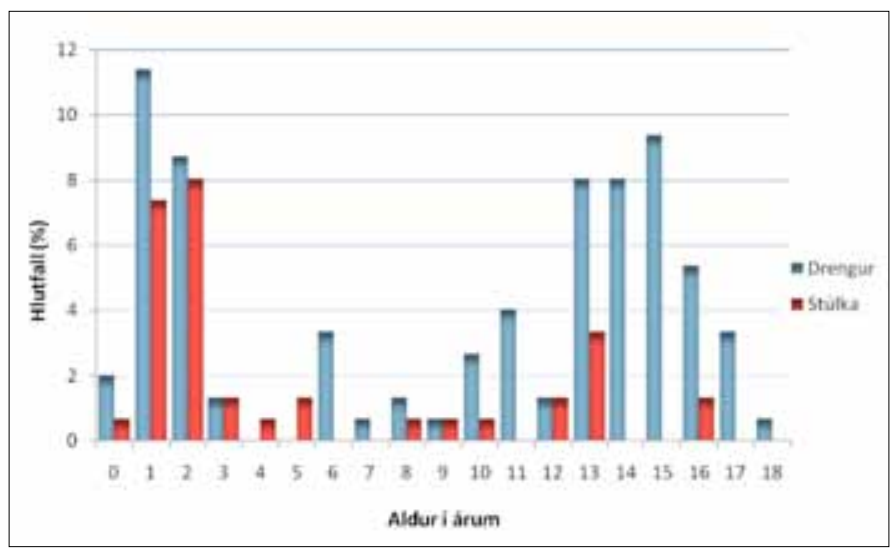

Mynd 2. Aldur og kyn barna frá 0-18 ára sem doöldu á Landspítala lengur en sólarhring vegna brunaslysa 2000-2008 (n=149). stöður peirra öðrum vestrænum rannsóknum hvað varðar kynjahlutfall, aldursdreifingu, slysavettvang og orsakir. Niðurstöður erlendra rannsókna sýna að forvarnir með fræðslu og stjórnsýsluaðgerðum sem lögleiða hitastýringu á neysluvatni leiða til fækkunar brunaslysa barna. ${ }^{6,15}$ Hér á landi hafa forvarnir gegn brunaslysum verið efldar síðustu ár og reglugerð sett um hámarkshita á neysluvatni. ${ }^{16,17}$

Alpjóðaheilbrigðismálastofnunin hvetur pjóðir til að fylgjast með próun brunaslysa og áhættupáttum með faraldsfræðilegum rannsóknum og kerfisbundinni skráningu. ${ }^{1}$ Miklar breytingar hafa orðið á íslensku pjóðfélagi frá síðustu rannsókn á brunaslysum barna og má nefna að börnum innflytjenda hefur fjölgað ríflega fimmfalt. ${ }^{18}$

Tilgangur rannsóknarinnar var að afla upplýsinga um brunaslys barna sem lögðust inn á Landspítala vegna brunaáverka á húð á tímabilinu 2000-2008. Leitað var svara við spurningunum hvort pörf sé á að auka forvarnir og breyta áherslum og endurskoða pætti í meðferð barna með brunasár á Landspítala.

\section{Efniviður og aðferöir}

Rannsóknin var lýsandi og afturskyggn og náði til allra barna yngri en 18 ára sem lögðust inn á Landspítala í sólarhring eða lengur vegna brunaáverka á húð á árunum 2000-2008.

Meðferð barna með alvarlega brunaáverka fer einungis fram á Landspítala. Í ársbyrjun 2005 fluttist bráðamóttaka og gjörgæslumeðferð barna með brunasár frá Landspítala Hringbraut yfir á Landspítala Fossvogi og paðan eru börnin send á Barnaspítala Hringsins.

Að fengnu leyfi framkvæmdastjóra lækninga, siðanefndar Landspítala og Persónuverndar var leitað einstaklinga sem höfðu fengið sjúkdómsgreininguna brunaáverki samkvæmt ICD-10 kóð- um. Upplýsingum var safnað úr sjúkraskrám og tvífarið yfir tæpan helming skránna (48\%). Eftirfarandi breytur voru skráðar: aldur við innlögn (skráđur í mánuðum hjá börnum tveggja ára og yngri), dagsetning og tími, kyn, pjóðerni, aðdragandi, vettvangur og brunavaldur flokkaðir á eftirfarandi hátt; vatn úr neysluvatnslögn, heitt vatn (pottar, hitakönnur), hveravatn, kaffi, te, aðrir vökvar (mjólk, súpur, grautar, sósur), heitur matur, eldur (gas, bensín, sprenging), skoteldar, snertibruni, efnabruni og rafbruni. Skráð var kæling á vettvangi, fyrsti viðkomustaður, hvort slys var tilkynnt barnaverndaryfirvöldum, innöndunaráverki, aðrir áverkar, staðsetning sára og dýpt, og útbreiðsla sem hlutfall af líkamsyfirborði. Upplýsingar um útbreiðslu voru teknar úr útskriftarnótu eða læknabréfi. Ef útbreiðsla var tilgreind á grófu bili var miðgildið skráð. Skráður var komutími á bráđamóttöku og á legudeild eða gjörgæslu, legutími og endurinnlögn innan 30 daga. Á Landspítala eru innlagnar- og útskriftardagur reiknaðir sem einn dagur og leyfi eru reiknuð inn í heildarlegudaga.

Skráðar voru upplýsingar um sárameðferð fyrstu prjá sólarhringa, sýklalyf, húðflutning og pá hversu löngu eftir slys (dagur slyss og dagur húðflutnings meðtaldir), fjöldi ferða á skurðstofu og tími á skurðstofu.

Unnið var með gögn í tölfræðiforritinu Statistical Package for the Social Sciences (SPSS), 11. útgáfu, og niðurstöður birtar um tíðni, meðaltöl, miðgildi, bil með hæsta og lægsta gildi og staðalfrávik (sf). Mann-Whitney próf var notað pegar breytur voru skoðaðar með tilliti til tímabila. Tölfræðileg marktækni var miðuð við p-gildi $<0,05$. Meðaltals árlegt nýgengi innlagna vegna brunaáverka var reiknað út frá miðársmannfjölda $\leq 17$ ára á rannsóknartímabilinu. ${ }^{18}$ Hlutföll voru reiknuð út frá fjölda pátttakenda í rannsókninni (N=149) nema annað sé tekið fram. 


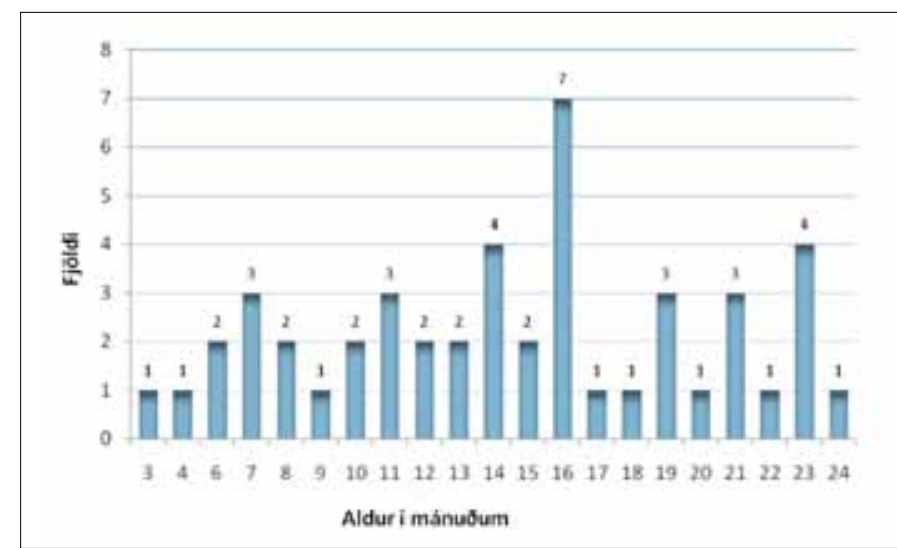

Mynd 3. Aldursdreifing barna frá 0-2 ára sem dvöldu á Landspítala lengur en sólarhring vegna brunaslysa 2000-2008 ( $n=32)$.

\section{Niðurstöður}

Alls uppfylltu 149 börn viðmið rannsóknarinnar um að vera yngri en átján ára og hafa dvalið í sólarhring eða lengur á Landspítala vegna brunaáverka á húð á árunum 2000-2008. Sjúkraskrár fimm barna fundust ekki en upplýsinga um pau var leitað í rafrænum gagnagrunni Landspítala.

Innlagnir voru 149, að meðaltali 16,5 börn á ári (mynd 1). Drengir voru 108 (72,5\%) og stúlkur 41 (27,5\%). Börn tveggja ára og yngri voru 57 (38,3\%) og börn fjögurra ára og yngri voru $62(41,6 \%)$. Börn í aldurshópnum fimm til níu ára voru 13 (8,7\%) og í aldurshópnum 10-15 ár voru 58 börn (39\%). Í elsta aldurshópnum, 16-18 ára, voru 16 börn $(10,8 \%)$. Slysin voru tíðust hjá börnum á fyrsta og öðru aldursári og á aldrinum 13 til 16 ára (mynd 2). Í flestum aldurshópum voru brunaslys algengari hjá drengjum (mynd 2). Hjá börnum yngri en tveggja ára voru brunaslys algengust við 16 mánaða aldur (mynd 3). Yngsta barnið sem brenndist var priggja mánaða gamalt.

Meðaltals árlegt nýgengi innlagna vegna brunaáverka á tímabilinu var 21/100 000 börn, en 32,3/100 000 hjá börnum yngri en fimm ára. Sextán börn $(10,7 \%)$ áttu foreldra sem báđir voru fæddir erlendis og var tíoni brunaslysa í peim hópi 162/100 000.

Tvö börn lögðust tvívegis inn vegna endurtekinna brunaáverka og var annað barnið með pekktan áhættupátt. Ekkert barn lést vegna brunaáverka á rannsóknartímanum.

\section{Aðdragandi slyss}

Aðdraganda slyss var lýst hjá $88,6 \%$ barna $(n=132)$. Vettvangur var í 50,8\% tilvika inni á heimili, oftast í eldhúsi (28\%), og pví næst á baðherbergi (8,3\%). Börn voru í gæslu nákominna í 47,8\% tilvika pegar slysið varð og par af í gæslu foreldra í 36\% tilvika og afa eða ömmu í 7,4\% tilvika. Hjá 17 börnum

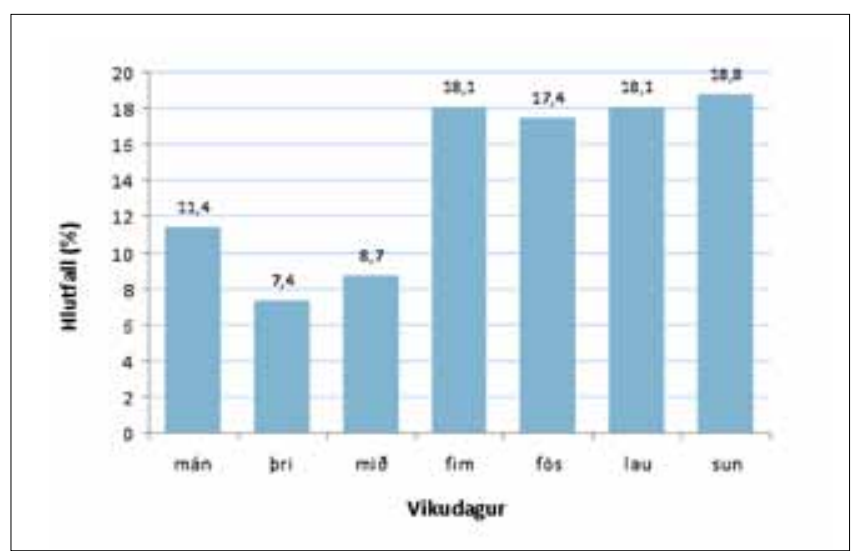

Mynd 4. Dreifing brunaslysa barna sem dvöldu á Landspítala lengur en sólarhring 2000-2008 eftir vikudögum ( $n=149)$.
(11,4\%) voru mögulegir áhættupættir til staðar, svo sem skyntruflanir, flogaveiki, athyglisbrestur, ofvirkni eða félagsleg vandamál. Hjá fimm börnum $(3,4 \%)$ var grunur um vanrækslu eða ofbeldi. Meirihluti slysa varð milli klukkan 17 og 21 (46,3\%) og pví næst milli klukkan 22 og 06 $(20,3 \%)$. Flest slysin áttu sér stað frá fimmtudegi til sunnudags (mynd 4) og í desember og janúar.

\section{Brunavaldur}

Brunavaldur (mynd 5) var skráour hjá 98,6\% barna (n=147). Um helmingur barnanna, eða 74 börn (50,3\%), brenndust á heitu vatni eða öðrum heitum vökvum og voru 55 peirra $(74,3 \%)$ fjögurra ára eða yngri. Börnin teygðu sig í ílát á borði eða eldavél, toguðu í snúrur á hitakönnum, klifruðu upp á hurð á bakaraofni og steyptu eldavélum yfir sig eða voru í fangi umsjónaraðila sem var með heitan drykk í höndunum. Önnur skriðu upp í handlaugar eða voru í baði og skrúfuðu frá heitavatnskrana. Eldur olli brunasárum hjá 30 börnum (20,4\%) og par af brenndust 22 börn vegna gass eða bensíns. Tuttugu og sex börn $(17,6 \%)$ brenndust af völdum skotelda og var meirihluti peirra á aldrinum 13-16 ára (77\%). Ellefu börn (7,5\%) brenndust við snertingu á heitum hlut. Prjú börn (2\%) brenndust á heitum matvælum, tvö $(1,4 \%)$ brenndust af ætandi efnum og eitt barn af völdum rafmagns. Ekkert barn brenndist vegna elds í íbúðarhúsnæði á rannsóknartímanum.

Á mynd 6 má sjá flokkun brunaslysa af völdum heits vatns og heitra vökva.

\section{Viðbrögð á vettvangi og dvalartími á bráðamóttöku}

Fyrstu meðferð var lýst fyrir 67,1\% slysanna $(n=100)$ og voru sár 78 barna $(78 \%)$ kæld á vettvangi. Börn fóru á bráðamóttöku í 76,9\% tilvika og paðan á barnadeild eða gjörgæslu með peirri undantekningu að fram til ársins 2005 fóru börn með alvarlega áverka beint á gjörgæsludeild 


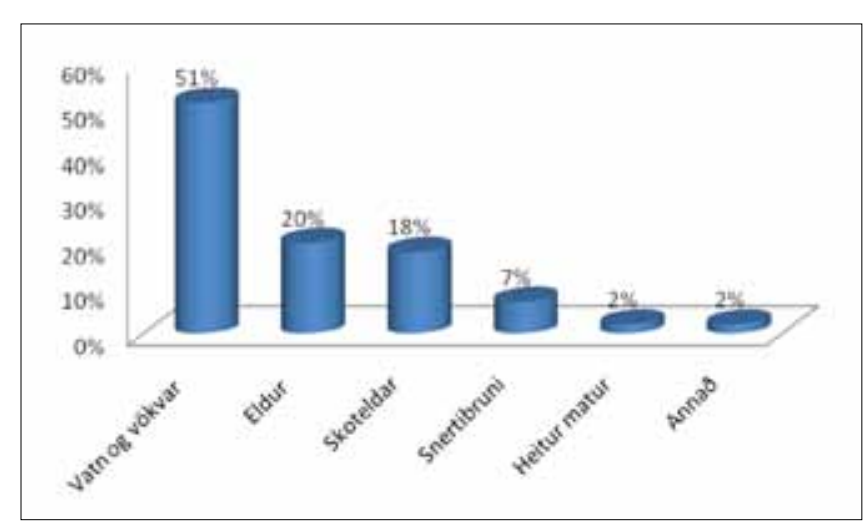

Mynd 5. Ástæður brunaslysa barna sem doöldu á Landspítala lengur en sólarhring 2000-2008 ( $n=147)$.

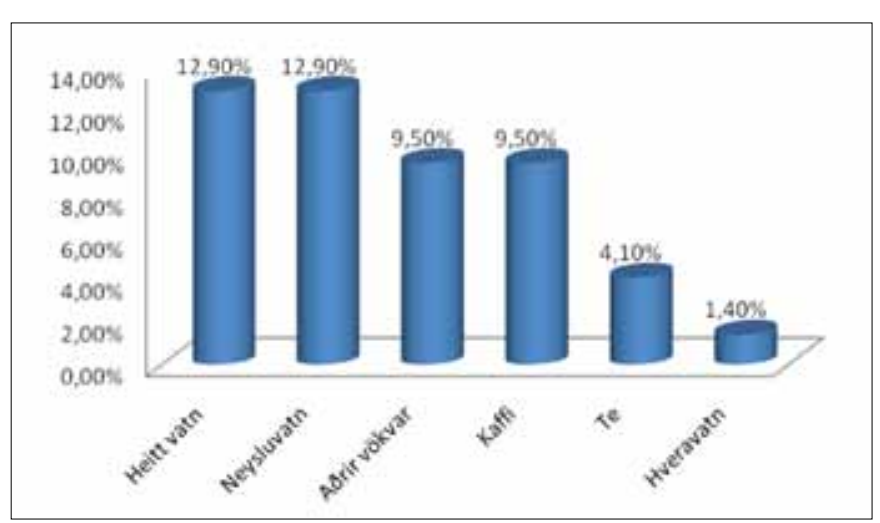

Mynd 6. Flokkun brunaslysa 74 barna af völdum vatns og vökva ( $n=147)$ sem dvöldu á Landspitala lengur en sólarhring árin 2000-2008. á Hringbraut án viðkomu á bráðamóttöku.

Dvalartími á bráđamóttöku var skráđur hjá $60,4 \%$ barna $(n=90)$. Dvalartími barna sem ekki fóru á gjörgæsludeild var að meðaltali tvær klukkustundir og 22 mínútur (142 mínútur), miðgildið 146 mínútur (sf 65,266; bil 25333). Tíminn var 13 mínútum lengri á seinni hluta rannsóknartímans (2005-2008) eða tvær klukkustundir og 30 mínútur (150 mínútur) borið saman við árin 2000-2004 sem var tvær klukkustundir og 17 mínútur (137 mínútur) en munurinn var ekki marktækur $(\mathrm{p}=0,28)$.

Börn sem fóru á gjörgæsludeild í Fossvogi dvöldu 37 mínútum skemur á bráðamóttöku, eða að meðaltali eina klukkustund og 45 mínútur (105 mínútur), miðgildið 98 mínútur (sf 67,06; bil 21-270).

\section{Alvarleiki áverka}

Útbreiðsla sára var skráð í 92\% tilvika (n=137) og var meðalútbreiðsla 8,23\%, miðgildið 5\% (sf 8,24; bil 1-55). Rúmur helmingur barnanna (52\%) var með útbreiðslu $\leq 5 \%$ og meirihluti barna $(81 \%)$ var með útbreiðslu $\leq 10 \%$. Níu börn $(6,6 \%)$ voru með útbreiðslu $\geq 20 \%$.

Dýpt áverka var skráð hjá 145 börnum og voru 3,4\% einungis með roða á húð (fyrstu gráðu bruni) og rúmur helmingur (60\%) með hlutpykktarbruna eingöngu en í mörgum tilvikum voru upplýsingar um dýpt sára misvísandi.

Staðsetning sára var skráð hjá öllum börnunum $(\mathrm{n}=149)$. Brunasár á höfði voru algengust, eða hjá 68 börnum $(45,6 \%)$. Næstalgengast var bruni á höndum, eða hjá 47 börnum (31,5\%), og í priðja sæti voru brunasár á brjóstkassa, hjá 31 barni $(20,8 \%)$ og sami fjöldi var með brunasár á fótleggjum. Innöndunaráverki var greindur hjá tveimur börnum (1,3\%). Tvö börn voru með aðra áverka auk brunaáverka. Eitt barn var flutt til útlanda til meðferðar.
Alls fóru 36 börn (24,2\%) á gjörgæslu og var brunaútbreiðsla skráð hjá 32 peirra. Meðalútbreiðsla áverka var 16\%, miðgildið 15 (sf 10,97; bil 4-55). Meðaldvalartími var sex dagar, miðgildið tveir dagar, (sf 10,37; bil 1-48). Legutími tveggja barna á gjörgæslu fannst ekki.

Heildarlegutími var skráour hjá 132 börnum og var meðallegutíminn 13 dagar, miðgildið níu dagar (sf 14,20; bil 1-97). Börn með $\geq 20 \%$ útbreiðslu áverka dvöldu að meðaltali 55 daga á sjúkrahúsi, miðgildið 57 dagar (sf 30,70; bil 11-97). Barnið sem fór utan var undanskilið í útreikningum á legutíma.

\section{Sárameðferð}

Lýsing á sárameðferð fyrstu prjá sólarhringa var skráð hjá 137 börnum (92\%). Sár í andliti og á höndum voru hreinsuð einu sinni til tvisvar á dag og önnur sár annan hvern dag að jafnaði. Sár í andliti og á eyrum voru í flestum tilvikum höfð án umbúða og borið á rakagefandi og græðandi smyrsl. Pokameðferð var notuð við handarbruna í 10,8\% tilvika. Vaselíngrisjur voru notaðar hjá $71,5 \%$ barna og $16 \%$ barna fengu silfurumbúðir $\left(\right.$ AquacelAg ${ }^{\circledR}$ ) en notkun peirra hófst árið 2005. Á seinni hluta rannsóknartímabilsins var svokölluð opin purrkmeðferð viðhöfð á gjörgæsludeild hjá premur börnum.

Sýklahemjandi áburður (silversúlfadíasín) var notaður hjá 37,9\% barna. Alls fengu 45 börn (31,3\%) sýklalyf í æð eða um munn vegna staðfestrar sýkingar í sárum eða gruns um sýkingu ( $\mathrm{n}=144)$. Húðágræðsla var gerð hjá 28 börnum eða $19,0 \%$ (n=147) og var meðaltími frá slysi og fram að ágræðslu 14,6 dagar, miðgildið 15 dagar (sf 7,46; bil 2-33).

Auk sárameðferða á legudeild og gjörgæslu fóru 35 börn (23,4\%) alls 107 ferðir á skurðstofu til húðágræðslu og sárameðferða af einhverju tagi. Á fyrri hluta rannsóknartímans voru ferðir 
á skurðstofu 76 eða 0,88 ferðir á hvern sjúkling (n=86) og á síðari hluta tímabilsins var 31 ferð á skurðstofu eða 0,5 ferðir á hvern sjúkling $(\mathrm{n}=63)$. Miðgildið fyrir dvalartíma á skurðstofu í hverri ferð var 204 mínútur (sf 337; bil 42-1200).

\section{Umræða}

Rannsókn pessi náđi til allra barna sem dvöldu á Landspítala vegna brunaáverka á húo á níu ára tímabili. Niðurstöður benda til að nýgengi innlagna barna vegna brunaáverka á tímabilinu hafi lækkað frá fyrri rannsókn ${ }^{14}$ eða úr 30,4/100 000 í 21/100 000. Fyrir börn yngri en fimm ára er breytingin meiri eða úr 78,6/100 000 börn $^{19}$ í 32,3/100 000 en pað er lágt samanborið við önnur lönd., 20, 21 Pennan árangur má mögulega rekja til aukinna forvarna ${ }^{16,17}$ og par á meðal til meiri notkunar á hitastýringarbúnaði heldur en var fyrrum. Hins vegar benda niðurstöður til pess að frekari aðgerða sé pörf hjá ákveðnum hópum barna og má par nefna börn með áhættupætti, unglingsdrengi og börn innflytjenda. Rannsóknin leiddi í ljós að tíðni brunaslysa meðal barna af erlendum uppruna var mun hærri en hjá rannsóknarhópnum í heild og hefur álíka próun verið lýst erlendis., ${ }^{52}$ Skoða parf hvernig best megi koma fræðslu og öðrum forvarnaraðgerðum til pessa hóps og meta hvort félagslegar aðstæður og par með talið ástand íbúđarhúsnæðis hafi áhrif á slysatíðni.

Hjá meirihluta barna fjögurra ára og yngri var heitt vatn og heitir vökvar ástæða brunans (71,6\%), sem rímar við aðrar rannsóknir. ${ }^{3-8,13,19,22-24}$ Vatn úr neysluvatnslögn hérlendis getur verið á bilinu 70-75 gráðu heitt ${ }^{17}$ og er vitað að 55 gráðu heitt vatn getur valdið djúpum bruna á 20-30 sekúndum hjá ungum börnum. Tíðni brunaslysa af völdum neysluvatns er á bilinu 14-43\% 1́ erlendum rannsóknum ${ }^{6,8,20,22}$ en í okkar rannsókn reyndist neysluvatn vera orsök brunaslysa í 12,9\% tilvika, borið saman við 15,2\% í rannsókn Ragnheiðar Elísdóttur og félaga, pó svo munurinn teljist ekki marktækur. Pessar niðurstöður benda til pess að hér á landi sé tíðni brunaslysa hjá börnum vegna neysluvatns sambærileg pví sem lægst gerist erlendis.

Brunaslysum af völdum skotelda fjölgaði marktækt, eða úr 5,5\% ${ }^{13} 1$ 17,6\% (p<0,0001). Einnig fjölgaði hlutfallslega peim slysum sem tengdust fikti með gas og bensín úr 5,2\% ${ }^{13}$ í 14,9\% og voru öll pessi slys algengust hjá drengjum á aldrinum 13-16 ára. Skýringar á fjölgun slysa vegna skotelda eru ekki augljósar en hugsanlega er aðgengi að slíkum varningi betra nú en áður var. Pessar niðurstöður benda til að auka purfi fræðslu til barna, unglinga og forráðamanna um skaðsemi skotelda og fikts með eldfim efni og íhuga hvort banna eigi aðgang að skoteldum til einkanota á sama hátt og samtök bandarískra barnalækna hafa lagt til. ${ }^{25}$

Augnslys voru ekki tekin með í pessa rannsókn pegar ekki fylgdi áverki á húð og eru innlagnir af völdum skotelda pví fleiri en hér kemur fram.

Niðurstöður erlendra rannsókna benda til að flogaveiki, ${ }^{26}$ athyglisbrestur og ofvirkni ${ }^{27}$ séu áhættupættir varðandi brunaslys. Í rannsókninni voru $11,4 \%$ barna með skyntruflanir, flogaveiki eða ofvirkni. Ætla má að forvarnir sem beinast að pessum hópi barna gætu skilað árangri. Grunur um vanrækslu eða ofbeldi var til staðar í 3,4\% tilvika, sem er lág tala borið saman við erlendar rannsóknir. ${ }^{28}$ Vönduð lýsing á aðdraganda og umgjörð brunaslysa barna og nákvæm fyrsta skoðun eykur líkur á að orsakir eins og vanræksla og ofbeldi séu greindar, og ættu brunasár af völdum neysluvatns á rassi, spangarsvæði eða útlimum, einkum á báðum fótum, að vekja grunsemdir. Ofangreindir pættir tengdir brunaáverkum hafa ekki verið skoðaðir fyrr hérlendis.

Dreifing slysa eftir aldri hefur lítið breyst frá fyrri rannsóknum. ${ }^{12,13}$ Brunaslys voru algengust hjá börnum fjögurra ára og yngri en börn í pessum aldursflokki voru 41,6\% af öllum hópnum. Hjá börnum tveggja ára og yngri voru slysin tíðust við 16 mánaða aldur. Börn voru oftast í gæslu foreldra og stödd í eldhúsi pegar slysið varð, sem er í samræmi við aðrar rannsóknir. ${ }^{4-6,22}$ Pessar niðurstöður árétta mikilvægi pess að öryggi ungra barna inni á heimilum sé í stöðugri endurskoðun og að foreldrum og forráðamönnum sé leiðbeint um áhættumat og úrbætur.

Upplýsingar um fyrstu meðferð á vettvangi voru einungis skráđar hjá 100 börnum (67\%) og voru sár kæld í 78\% skráðra tilvika, sem er svipað hlutfall og kom fram í ástralskri rannsókn,, ${ }^{23}$ en par sem upplýsingar um meðferð á vettvangi voru ekki til staðar hjá 33\% barna er óvarlegt að fullyrða um pekkingu almennings á mikilvægi kælingar við bruna.

Útbreiðsla áverka var ekki skráð hjá 12 börnum $(8,1 \%)$ og einnig var í mörgum tilvikum verulegt ósamræmi milli mats á útbreiðslu við innlögn og upplýsinga í útskriftarnótum og læknabréfum. Pegar brunaáverki er ofáætlaður er meðal annars hætta á yfirvökvun og eru ung börn í sérstakri áhættu og fram hefur komið verulegt van- eða ofmat á útbreiðslu sára hjá börnum. ${ }^{7}$ Nákvæm greining á útbreiðslu sára er mikilvæg, meðal annars fyrir mat á vökvapörf og hvort innlögn á gjörgæslu sé nauðsynleg. 
Meðalútbreiðsla brunasára var ápekk pví sem kom fram í rannsókn Ragnheiðar Elísdóttur og félaga pó svo hlutfallslega fleiri börn hafi lagst inn á gjörgæsludeild í okkar rannsókn, eða 24,2\% á móti 6,9\%. Meðalútbreiðsla brunasára hjá gjörgæsluhópnum var einnig nokkuð lægri borin saman við tölur frá Finnlandi, ${ }^{7}$ eða $16 \%$ á móti 26\%, en íslenskar rannsóknir til samanburðar liggja ekki fyrir.

Af fyrirliggjandi gögnum er ekki hægt að sjá beinar ástæður fyrir fjölgun innlagna á gjörgæslu en hugsanlega getur staðsetning bráðamóttöku og barnadeildar hvorrar í sínum bæjarhluta skipt máli.

Börn sem fóru ekki á gjörgæsludeild dvöldu á bráðamóttöku að meðaltali tvær klukkustundir og 30 mínútur á árunum 2005-2008 og lengdist dvalartíminn að meðaltali um 13 mínútur eftir að brunameðferð flutti á Landspítala Fossvogi um áramót 2005. Börn sem fóru á gjörgæsludeild dvöldu að meðaltali í eina klukkustund og 45 mínútur á bráðamóttöku en á árunum 20002005 fóru börn beint á gjörgæslu, án viðkomu á bráđamóttöku. Dvalartíminn var ekki skráður hjá um 39\% barnanna. Mikilvægt er að börn séu færð sem fyrst á meðferðardeild ${ }^{29}$ og skoða parf hvort pað sé börnum í hag að stytta dvalartíma á bráðamóttöku og setja viðmið um hvað gæti talist viðunandi tími. Rannsóknir á dvalartíma brunasjúklinga á slysadeildum fundust ekki til samanburðar.

Á árunum 2005-2008 fækkaði ferðum barna á skurðstofu til sárameðferða borið sama við árin 2000-2005. Bætt aðstaða til sára- og verkjameðferða á Barnaspítala Hringsins, notkun silfurumbúða og aukið aðgengi að sérhæfðum hjúkrunarfræðingum skýra að einhverju leyti pá próun að sárameðferð á skurðstofu verður fátíðari. Auk pæginda fyrir barn og foreldra má ætla að minni notkun á skurðstofum lækki kostnað. Sjúklingar með silfurumbúðir eingöngu voru of fáir til pess að unnt væri að beita tölfræðilegum prófum til að skoða árangur, svo sem áhrif á legutíma. Hlutfall barna sem purfti húðflutning (19\%) var ívið hærra en fram kemur í sambærilegri breskri rannsókn $(14,4 \%)^{8}$ en samanburður við erlendar rannsóknir er erfiður pví aldursviðmið og aðferðafræði eru breytileg milli rannsókna og hópurinn í pessari rannsókn er lítill.

Meðallegutími lengdist um sólarhring, eða úr 12 dögum $^{13}$ í 13 daga, en munurinn var ekki marktækur. Í evrópskum rannsóknum er meðallegutími 5,5 til 22 dagar.6, 8, 20, 21 Ein af ástæðum pess að legutími hefur ekki styst hérlendis gæti verið breytt samfélagsgerð, eins og tölur um innflytjendur benda til ${ }^{17}$ og geta flóknar félagslegar aðstæður fjölskyldunnar valdið pví að barni er haldið lengur á barnadeild en annars væri. Hafa ber í huga að langur legutími er ein ástæða pess að meðferð brunasjúklinga er kostnaðarsöm. ${ }^{30}$

Styrkur pessarar rannsóknar er einkum sá að öll börn á Íslandi með alvarlega brunaáverka á rannsóknartímanum voru pátttakendur. Til að efla áreiðanleika gagnasöfnunar var tvífarið yfir tæpan helming sjúkraskránna, auk pess sem reyndir hjúkrunarfræðingar söfnuðu gögnum. Veikleiki rannsóknarinnar er meðal annars rannsóknarsniðið sem var afturskyggnt og var skráning í sjúkraskrár í mörgum tilvikum ónákvæm eða ekki til staðar. Ennfremur var breytileiki milli einstaklinga mikill og hópurinn lítill, sem gerði marktækni- og fylgniútreikninga ekki mögulega.

\section{Ályktun}

Við teljum brýnt að auka öryggi barna inni á heimilum og beina forvörnum sérstaklega að áhættuhópum; börnum fjögurra ára og yngri, börnum innflytjenda, börnum með skyntruflanir, flogaveiki og hegðunarvanda og drengjum 13-16 ára. Fræðsla parf að beinast að foreldrum, og ekki síður aðverðandi foreldrum og öðrum nákomnum. Hitastýringarbúnaður fyrir neysluvatn ætti að vera í öllu íbúðarhúsnæði. Skoða parf ávinning af pví að takmarka aðgengi að skoteldum til einkanota. Auka parf fræðslu til almennings um mikilvægi kælingar á vettvangi. Efla parf fyrsta mat á útbreiðslu sára og greina pætti sem hafa áhrif á dvalartíma á bráðamóttöku, innlagnir á gjörgæsludeild og á legutíma. Skráningu í sjúkraskrár parf að bæta. Tímabært er að taka upp samræmda skráningu lágmarksupplýsinga fyrir brunaslys í sértækan gagnagrunn sem meðal annars gæti eflt gæðaeftirlit og pjónustu við börn með brunaáverka á Íslandi.

\section{Pakkir}

Pakkir fá Örn Ólafsson tölfræðingur fyrir aðstoð við tölfræðilega úrvinnslu, Ingibjörg Richter kerfisfræðingur, Fríða Ó. Ólafsdóttir hjúkrunarfræðingur og Anna María Pórðardóttir sérfræðingur í bráðahjúkrun fyrir ráđgjöf. Samtök um sárameðferð og B-hluti vísindasjóðs Félags íslenskra hjúkrunarfræðinga fá pakkir fyrir veittan styrk.

\section{Heimildir}

1. Mock C, Peck M, Peden M, Krug E, eds. A WHO plan for burn prevention and care. World Health Organization, Geneva 2008. 
2. Burd A, Yuen C. A global study of hospitalized paediatric burn patients. Burns 2005; 31: 432-8.

3. Wasiak K, Spinks A, Ashby K, Clapperton A, Cleland $\mathrm{H}$, Gabbe B. The epidemiology of burn injuries in an Australian setting 2000-2006. Burns 2009; 35: 1124-32.

4. Drago DA. Kitchen scalds and thermal burns in children five years and younger. Pediatrics 2005; 115: 10-6.

5. Carlsson A, Uden G, Hakansson A, Karlsson ED. Burn injuries in small children, a population-based study in Sweden. J Clin Nursing 2006; 15: 129-34.

6. Nguyen DQA, Tobin S, Dickson WA, Potocar T. Infants under 1 year of age have a significant risk of burn injury. Burns 2008; 34: 863-7.

7. Papp A, Rytkönen T, Koljonen V, Vuola J. Paediatric ICU burns in Finland 1994-2004. Burns 2008; 34: 339-44.

8. Collin T, Jeffery S, Reid C. Bath-water scalds in children and thermostatic mixer valves. Burns 2006; 32: 909-12.

9. Liber JM, List D, Van Loey NE, Kef S. Internalizing problem behavior and family environment of children with burns: a Dutch pilot study. Burns 2006; 32: 165-71.

10. Stoddard FJ, Ronfeldt H, Kagan J, et al. Young burned children: the course of acute stress and physiological and behavioural responses. Am J Psychiatry 2006; 163: 108490.

11. Björnsson S. Brunasjúklingar á barnadeild Landspítalans. Læknablaðið 1970; 56: 95-106.

12. Porgrímsson $\mathrm{S}$, Björnsson Á. Brunasjúklingar á Landspítalanum á árunum 1964-1973. Fyrri grein Læknablaðið 1982; 68/Fylgirit 13: 66-70.

13. Elísdóttir R, Lúðvíksson P, Einarsson Ó, Porgrímsson S, Haraldsson Á. Brunaslys barna á Íslandi: Innlagnir á árunum 1982-1995. Læknablaðið 1997; 83: 303-8.

14. Elísdóttir R, Lúdvígsson P, Einarsson Ó, Thorgrímsson S, Haraldsson Á. Paediatric burns in Iceland. Hospital admissions 1982-1995, a population based study. Burns 1999; 25: 149-51.

15. Ytterstad B, Smith GS, Coggan CA. Harstad injury prevention study: prevention of burns in young children by community based intervention. Inj Prev 1998; 4: 17680 .

16. Reglugerð um hollustuhætti, 941/2002,14.gr. www. heilbrigdisraduneyti.is/log-og-reglugerdir/maí 2010
17. Orkuveita Reykjavíkur: www.stillumhitann.is/ágúst 2010

18. Hagstofa Íslands: www.hagstofan.is/ágúst 2010.

19. Guðmundsson GS, Porgrímsson S, Einarsson Ó. Faraldsfræði alvarlegra brunaáverka á Íslandi 1988-1992. Læknablaðið 1997; 83: 503-9.

20. Celko AM, Grivna M, Danová J, Barss P. Severe childhood burns in the Czech republic: risk factors and prevention. Bull World Health Organ 2009; 87: 347-81.

21. Onarheim $\mathrm{H}$, Jensen SA, Rosenberg ABG.The epidemiology of patients with burn injuries admitted to Norwegian hospitals in 2007. Burns 2009; 35: 1142-6.

22. Rimmer RB, Weigand S, Foster KN, et al. Scald burns in young children-a review of Arizona burn center pediatric patients and a proposal for prevention in the Hispanic community. J Burn Care Res 2008; 29: 595-605.

23. Cuttle L, Kravchuk O, Wallis B, Kimble RM. An audit of first-aid treatment of pediatric burns patients and their clinical outcome. J Burn Care Res 2009; 30: 1028-34.

24. Rawlins JM, Khan AA, Shenton AF, Sharpe DT Epidemiology and outcome analysis of 208 children with burns attending an emergency department. Pediatr Emerg Care 2007; 23: 289-93.

25. American Academy of Pediatrics, committee on injury and poison prevention. Fireworks-related injuries to children. Pediatrics 2001; 108: 190-1.

26. Ansari Z, Brown K, Carson N. Association of epilepsy and burns - a case control study. Aust Fam Physician 2008; 37: 584-9.

27. Badger K, Anderson L, Kagan RJ. Attention deficithyperactivity disorder in children with burn injuries. J Burn Care Res 2008; 29: 724-9.

28. Thomb, BD. Patient and injury characteristics, mortality risk, and length of stay related to child abjuse by burning: Evidence from a national sample of 15,802 pediatric admissions. Ann Surg 2008; 247:3, 519-23.

29. American Academy of Pediatrics. Joint policy statement - Guidelines for care of children in the emergency department. Pediatrics 2009; 124:1233-43.

30. Klein MB, Hollingworth W, Rivara FP, et al. Hospital costs associated with pediatric burn injury. J Burn Care Res 2008; 29: 632-7.

\section{Burn injuries in children: Admissions at Landspitali University Hospital in Iceland 2000-2008}

Background: Causes of burn injuries in children are universally associated with social and environmental factors. Epidemiological studies are therefore important in identifying risk factors and for planning preventive interventions.

Methods: Children younger than 18 years with skin burns who were treated as inpatients at Landspitali University Hospital over a 9-year period, 2000 and 2008, were included in this retrospective descriptive study. Data was collected from medical records.

Results: Of 149 children included in the study $41.6 \%$ were four years old or younger. The average annual incidence of hospital admissions was $21 / 100000$. Cold water as first aid was applied in $78 \%$ of cases. Half of the accidents occurred in the home where a close family member was the caretaker. Risk factors were identified in $11.4 \%$ of the accidents and abuse or neglect was suspected in 3.4\% of cases. Scalds were the most common type of burn injury $(50.3 \%)$ followed by burns caused by fire $(20.4 \%)$ including gas or petrol (14.9\%) and fireworks (17.6\%). The most common source of scalds was exposure to hot water from hot water mains $(12,9 \%)$ and heated water $(12,9 \%)$. The mean time from emergency room admission to the paediatric ward was two hours and 22 minutes. The mean length of stay was 13 days; median 9 days (range 1-97). Conclusion: Incidence of hospital admissions for burn injury has decreased when compared with earlier Icelandic studies. Children four years and younger and boys between 13-16 years old are most at risk for burn injuries. Stronger preventive measures as well as better documentation of burn accidents are imperative.

Baldursdottir L, Thorsteinsson LS, Auðolfsson G, Baldursdottir ME, Sigurvinsdottir BO, Gisladottir V, Sigurðardottir AO, Rosmundsson P. Burn injuries in children: Admissions at Landspitali University Hospital in Iceland 2000-2008 Icel Med J 2010; 96: 683-9. Key words: burns, children, scalds, prevention, epidemiology

Correspondence: Lovisa Baldursdottir lovisaba@landspitali.is 